\title{
Tandem Cuprous Oxide/Silicon Microwire Hydrogen-Evolving Photocathode with Photovoltage Exceeding 1.3 V
}

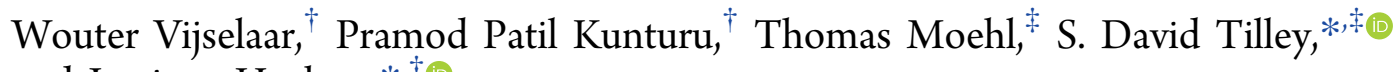
and Jurriaan Huskens ${ }^{*}+$ ○

${ }^{\dagger}$ Molecular Nanofabrication Group, MESA + Institute for Nanotechnology, Faculty of Science and Technology, University of Twente, P.O. Box 217, 7500 AE Enschede, The Netherlands

${ }^{\ddagger}$ Department of Chemistry, University of Zurich, Winterthurerstrasse 190, CH-8057 Zurich, Switzerland

\author{
Supporting Information
}

ABSTRACT: Large research efforts have been devoted to optimizing the output of earth-abundant photoabsorbers in solar-to-fuel (S2F) devices. Here, we report a $\mathrm{Cu}_{2} \mathrm{O} / \mathrm{Ga}_{2} \mathrm{O}_{3}$ heterojunction/Si microwire photocathode with an underlying buried radial $\mathrm{Si} p-n$ junction, which achieves efficient light harvesting across the visible spectrum to over $600 \mathrm{~nm}$, reaching an external quantum yield for hydrogen generation close to $80 \%$, with a photocurrent onset above $+1.35 \mathrm{~V}$ vs RHE, a photocurrent density of $\sim 10 \mathrm{~mA} / \mathrm{cm}^{2}$ at $0 \mathrm{~V}$ vs RHE, and an ideal regenerative efficiency of $5.51 \%$. We show stepby-step the effects of every photocathode design element (i.e., Si p$n$ junction, $\mathrm{Cu}_{2} \mathrm{O}$ layer thickness, microwire length, microwire pitch, etc.) on the overall efficiency of our final microwire $\mathrm{Si} / \mathrm{Cu}_{2} \mathrm{O}$ photocathode by comparing every addition to a baseline $\mathrm{Cu}_{2} \mathrm{O}$ photocathode. Lastly, we show a stable operation exceeding $200 \mathrm{~h}$ at a bias potential of $+1.0 \mathrm{~V}$ vs RHE, with an average current density of $4.5 \mathrm{~mA} / \mathrm{cm}^{2}$.

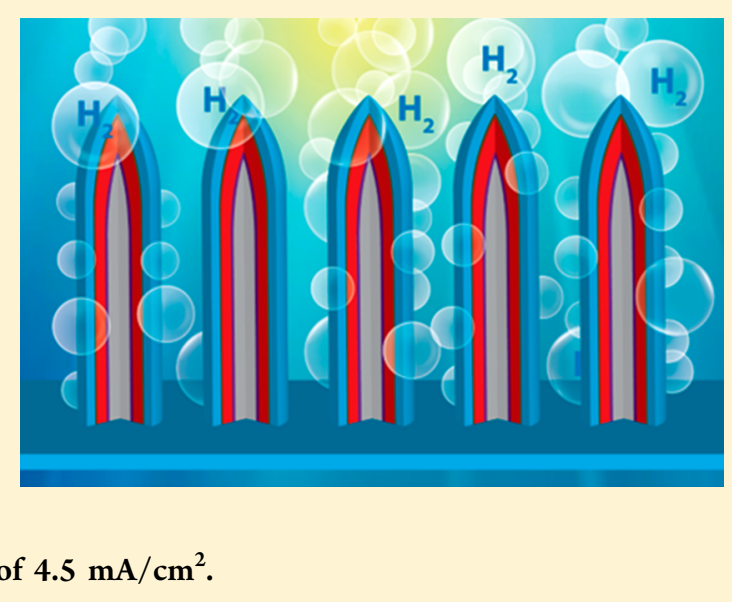

S olar-to-fuel (S2F) is the concept of turning solar energy into a storable fuel in an integrated process. To fabricate a fully integrated, efficient S2F device based on photoelectricity, a single or set of semiconductors must be combined with a proper electrocatalyst. Many single semiconductors are investigated as possible candidates for a photoanode (e.g., $\mathrm{Fe}_{2} \mathrm{O}_{3},{ }^{1-3} \mathrm{BiVO}_{4},{ }^{4-6} \mathrm{WO}_{3}{ }^{7,8} \mathrm{TiO}_{2},{ }^{9-12}$ or $\mathrm{ZnO}^{13-15}$ ) or photocathode (e.g., III-V systems, ${ }^{12} \mathrm{CuO},{ }^{16,17}$ $\mathrm{Cu}_{2} \mathrm{O},{ }^{18} \mathrm{Si},{ }^{19,20}$ or $\left.\mathrm{SiC}^{21}\right)$. However, to date, not a single semiconductor produces both a high photocurrent and enough photovoltage to drive a solar fuel reaction (e.g., production of hydrogen $\left(\mathrm{H}_{2}\right)$ and oxygen $\left.\left(\mathrm{O}_{2}\right)\right)$ at an acceptable efficiency.

Fountaine et al. and others showed that a combination of semiconductors with bandgaps of approximately 1.8 and $1.0 \mathrm{eV}$ would give theoretically the highest overall efficiency. ${ }^{22-25}$ In an ideal case, each material creates an equal current density (i.e., current matching), and an enhanced photovoltage $\left(V_{o c}\right)$ is achieved when the stack is in series. Key considerations in selecting the appropriate materials are photon-to-electron conversion and efficient charge transport across all layers, in order to convert the electrons to hydrogen. A possible combination of materials could be cuprous oxide $\left(\mathrm{Cu}_{2} \mathrm{O}\right)$ in series with silicon $(\mathrm{Si})$ because they have bandgaps of 2.0 and

$1.1 \mathrm{eV}$, respectively. Both materials are extensively investigated as materials in photovoltaic (PV) cells, $^{26-31}$ are earthabundant, are nontoxic, and are relatively cost-effective to produce. However, a directly coupled tandem cell between $\mathrm{Si}$ and $\mathrm{Cu}_{2} \mathrm{O}$ has never been investigated. Furthermore, both materials have their own drawbacks, which need to be addressed to improve the overall efficiency for a possible tandem cell. A notable feature for all of the electrodeposited $\mathrm{Cu}_{2} \mathrm{O}$ systems, whether used as a photocathode or in a solar cell, is the poor conversion of photons with wavelengths of 500-600 nm due to the mismatch between the absorption depth of the photons and the diffusion length of the photogenerated electrons as a result of the relatively high acceptor concentration in electrodeposited films. Luo et al. surpassed this problem by the fabrication of $\mathrm{Cu}_{2} \mathrm{O}$ nanowires, which greatly enhanced the current density up to $9 \mathrm{~mA} / \mathrm{cm}^{2}$ at $0 \mathrm{~V}$ vs RHE. ${ }^{32}$ Pan et al. improved this and reported recently the best oxide photocathode known today with a $\mathrm{Cu}_{2} \mathrm{O} / \mathrm{Ga}_{2} \mathrm{O}_{3}$ heterojunction, which achieves a photocurrent onset over $1 \mathrm{~V}$

Received: July 1, 2019

Accepted: August 26, 2019

Published: August 26, 2019 
A

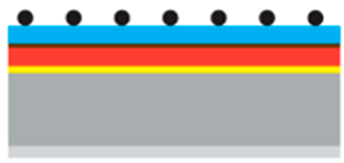

p-type silicon

gold
B

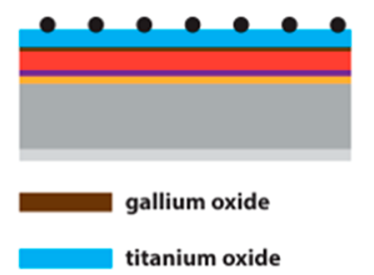

C

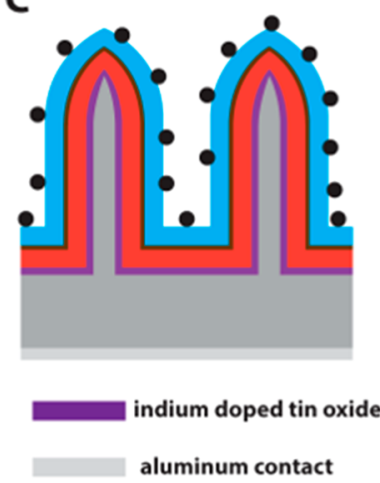

D

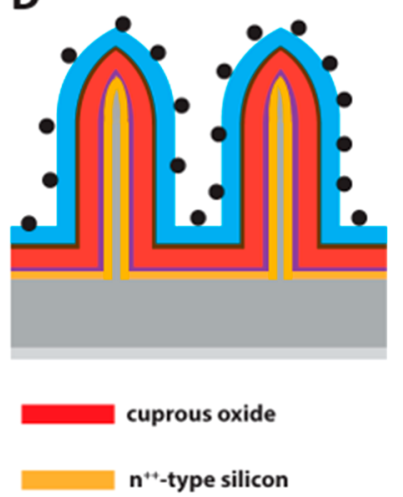

Figure 1. Schematic representation of the different device layer architectures (not to scale). (A) Si substrate (i.e., not used as a photoabsorber) with a layer of gold $(150 \mathrm{~nm})$, electrodeposited $\mathrm{Cu}_{2} \mathrm{O}(200 \mathrm{~nm})$, an emitter of $\mathrm{Ga}_{2} \mathrm{O}_{3}(20 \mathrm{~nm})$, a passivation layer of TiO $(100 \mathrm{~nm})$, and a $\mathrm{RuO}_{x}$ catalyst $(\sim 2 \mathrm{~nm})$. (B) Planar tandem stack of a Si substrate with a planar $\mathrm{p}-\mathrm{n}$ junction, ITO $(75 \mathrm{~nm}) / \mathrm{Au}$ particles $(5$ $\mathrm{nm})$, electrodeposited $\mathrm{Cu}_{2} \mathrm{O}(150 \mathrm{~nm})$, an emitter of $\mathrm{Ga}_{2} \mathrm{O}_{3}(20 \mathrm{~nm})$, a passivation layer of $\mathrm{TiO}_{2}(100 \mathrm{~nm})$, and a $\mathrm{RuO}_{x}$ catalyst $(\sim 2 \mathrm{~nm})$. (C) Si microwire array $\left(15 \mu \mathrm{m}\right.$ in length), without a $\mathrm{p}-\mathrm{n}$ junction, with ITO $(75 \mathrm{~nm}) / \mathrm{Au}$ particles, electrodeposited $\mathrm{Cu}_{2} \mathrm{O}(200 \mathrm{~nm})$, an emitter of $\mathrm{Ga}_{2} \mathrm{O}_{3}(20 \mathrm{~nm})$, a passivation layer of $\mathrm{TiO}_{2}(100 \mathrm{~nm})$, and a $\mathrm{RuO}_{x}$ catalyst $(\sim 2 \mathrm{~nm})$. (D) Si microwire array $(15 \mu \mathrm{m}$ in length) containing a radial $\mathrm{p}-\mathrm{n}$ junction, with ITO $(75 \mathrm{~nm}) / \mathrm{Au}$ particles, electrodeposited $\mathrm{Cu}_{2} \mathrm{O}(200 \mathrm{~nm})$, an emitter of $\mathrm{Ga}_{2} \mathrm{O}_{3}(20 \mathrm{~nm})$, a passivation layer of $\mathrm{TiO}_{2}(100 \mathrm{~nm})$, and a $\mathrm{RuO}_{x}$ catalyst $(\sim 2 \mathrm{~nm})$.

vs RHE and a photocurrent density of $\sim 10 \mathrm{~mA} / \mathrm{cm}^{2}$ at $0 \mathrm{~V}$ versus RHE. ${ }^{33}$ The smaller energy band offset and favorable band alignment (conduction band) between the $\mathrm{Cu}_{2} \mathrm{O}$ and $\mathrm{Ga}_{2} \mathrm{O}_{3}$ layers diminishes interfacial recombination. ${ }^{33-36}$ As a result, the energy for the splitting of the quasi-Fermi levels between the two oxides is larger, hence leading to a higher photovoltage. However, $\mathrm{Cu}_{2} \mathrm{O}$ nanowires are grown from a thick copper $(\mathrm{Cu})$ film. A residual $\mathrm{Cu}$ film remains after fabrication and would block the incoming light for a possible underlying second low bandgap absorber (e.g., Si) that could further increase the overall voltage and therefore overall efficiency of a S2F device. Furthermore, the photovoltage $(\sim 1$ $\mathrm{V}$ ) is not enough to produce hydrogen in a standalone configuration. Even with state-of-the-art materials (e.g., $\mathrm{Pt}$ as reduction and $\mathrm{IrO}_{x}$ as oxidation catalyst), the overall required voltage to split water is theoretically $1.23 \mathrm{~V}$ but practically $>1.4$ $\mathrm{V}^{37}$

Paracchino et al. have shown that, besides a high photovoltage, also passivation and catalysis are important contributors to a high overall efficiency. ${ }^{38}$ They investigated different passivation layer thicknesses of titanium oxide $\left(\mathrm{TiO}_{2}\right)$ and found that they could extend the stability significantly. Such a passivation layer is now well understood, and stability is even further increased. ${ }^{33}$ To reduce the overpotential for the electrochemical hydrogen evolution reaction, a stable catalyst is required. Tilley et al. showed that one of the best performing and, above all, stable hydrogen evolution catalyst is ruthenium oxide $\left(\mathrm{RuO}_{x}\right) \cdot{ }^{39}$ Furthermore, in order not to obstruct the light absorption of the underlying layers, nanoparticles are easily deposited by galvanostatic photodeposition. ${ }^{40}$

In order to increase the photovoltage, a second semiconductor can be added either behind or in front of the $\mathrm{Cu}_{2} \mathrm{O}$ stack. Bismuth vanadate as a high-bandgap photoanode has been used in the literature in combination with a lowerbandgap material (e.g., $\left.\mathrm{Cu}_{2} \mathrm{O}\right){ }^{6,33,41}$ However, the main reason for the low overall performance is the lack of overall photovoltage. ${ }^{42}$ The bandgap of $\mathrm{Si}$ is almost ideal, according to simulations as stated above. However, planar $\mathrm{Si}$ has an inherently high reflectivity $(\sim 30 \%)$ over a broad spectrum. ${ }^{43}$
The reflectivity can be lowered substantially $(<1 \%)$ by introducing a $\mathrm{Si}$ microwire array with a radial $\mathrm{p}-\mathrm{n}$ junction, and such arrays have proven to be very effective PV cells. ${ }^{44,45}$ The microwires mostly improve the overall efficiency by improved charge collection due to the lower reflectivity and thereby increase the current density. Furthermore, in a tandem cell (e.g., in combination with $\mathrm{Cu}_{2} \mathrm{O}$ ), $\mathrm{Si}$ microwires with a junction can increase the photovoltage of the overall stack. However, direct coupling to $\mathrm{Cu}_{2} \mathrm{O}$ has never been shown.

Here we show a geometry for a S2F device that is based on tapered Si microwire arrays to overcome the aforementioned problems (i.e., low light absorption and photovoltage of solely $\left.\mathrm{Cu}_{2} \mathrm{O}\right){ }^{46}$ We present the realization and stability of a microwire $\mathrm{Si} / \mathrm{Cu}_{2} \mathrm{O}$ tandem cell with a radial $\mathrm{p}-\mathrm{n}$ junction in the $\mathrm{Si}$ microwires. We show that the addition of $\mathrm{Si}$ microwires enhances the overall absorption of the $\mathrm{Cu}_{2} \mathrm{O}$ stack. Furthermore, the introduction of an underlying radial $\mathrm{Si} p-n$ junction increases the overall photovoltage. In order to show the addition of each aspect of the device, we compare the stacks with and without a microwire architecture and with and without a junction in the Si. In this manner, we can deconvolute the influence of every step. Additionally, we investigated the roles of ALD-grown $n-\mathrm{Ga}_{2} \mathrm{O}_{3}, \mathrm{TiO}_{2}$ overlayers, and $\mathrm{RuO}_{x}$ as a cocatalyst in aiding protection from the electrolyte environment and PEC performance. Lastly, we optimized the $\mathrm{Cu}_{2} \mathrm{O}$ layer thickness, and the pitch and height of the $\mathrm{Si}$ microwires, in order to obtain the highest overall photoconversion efficiency, photovoltage, and current density.

We fabricated four different types of photocathodes to investigate the effect of every change in the stack. Figure 1 is a schematic representation of the different stacks that we are comparing throughout this Letter. The sample depicted in Figure 1A is used as a baseline, which is fabricated as described in the literature. ${ }^{47}$ Hereafter, a planar buried $\mathrm{p}-\mathrm{n}$ junction in the $\mathrm{Si}$ is introduced, Figure $1 \mathrm{~B}$, to assess the impact of the junction on the produced photovoltage by the underlying $\mathrm{Si}$. Therefore, the solid Au layer in Figure 1A is replaced by a transparent ITO/Au nanoparticle layer, similar to the transparent FTO/Au layer as described by Dias et al. ${ }^{47}$ Lastly, Si 

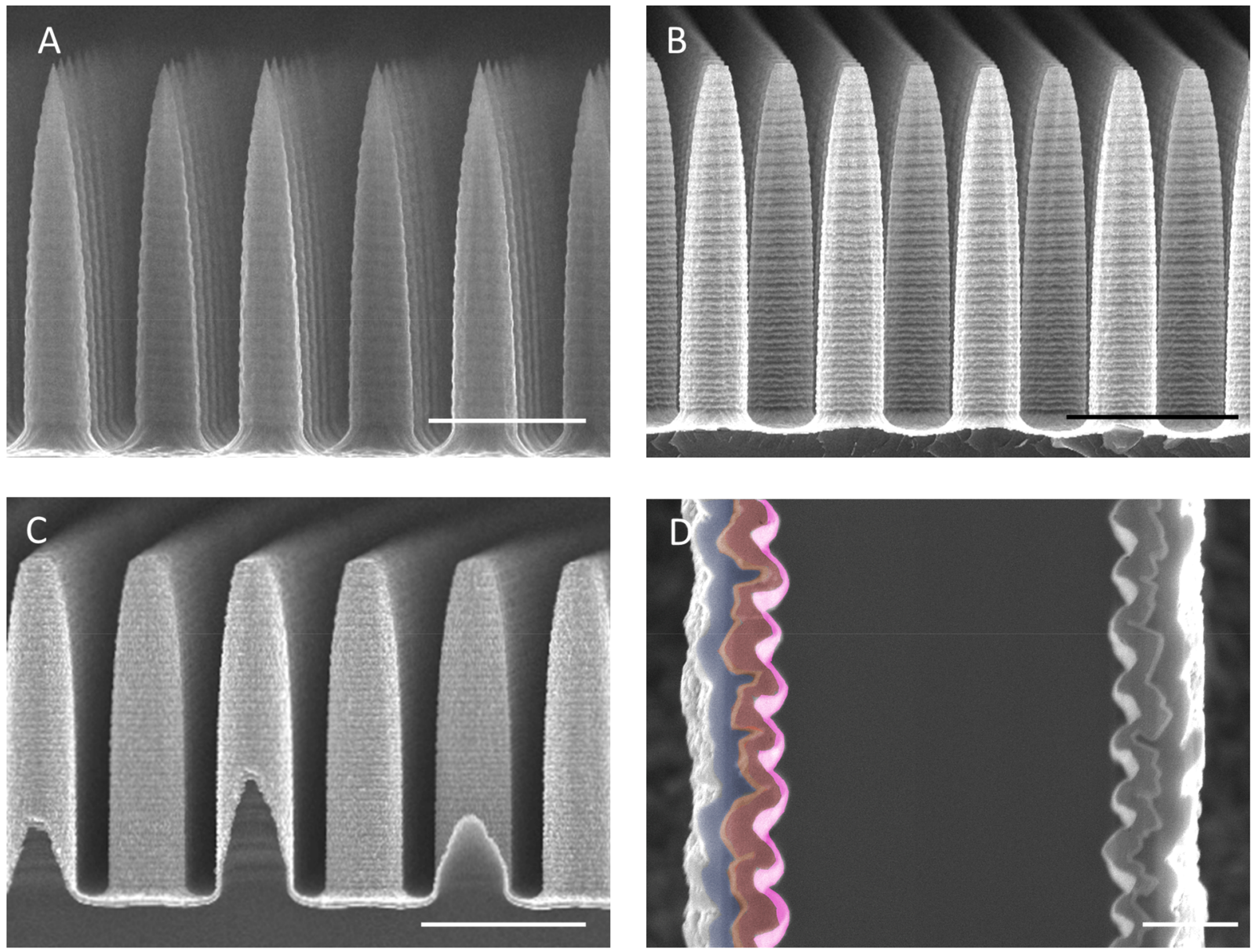

Figure 2. HR-SEM images of the microwire array samples after each of the main process steps of the fabrication process: (A) after the wetetch step to taper the $\mathrm{Si}$ microwires, (B) after sputtering of the ITO/Au layer over the microwires, (C) after the electrodeposition of $\mathrm{Cu}_{2} \mathrm{O}$, and (D) after completing the whole fabrication process and cutting (by FIB) a microwire in the length direction. In (D), the left-hand side is false-colored, ITO/Au (pink), $\mathrm{Cu}_{2} \mathrm{O}$ (red), $\mathrm{Ga}_{2} \mathrm{O}_{3}$ (orange), and $\mathrm{TiO}_{2}$ (blue). The scale bars in (A-C) are $5 \mu \mathrm{m}$; that in (D) is $500 \mathrm{~nm}$.

microwires are introduced in the stack of materials from Figure $1 \mathrm{~B}$ to obtain stacks without (Figure 1C) and with (Figure 1D) a radial $\mathrm{p}-\mathrm{n}$ junction. Therefore, we can assess the contributions of the additions of the microwire and the junction separately.

For the structured samples, we etched straight $\mathrm{Si}$ microwires, with a width of $4 \mu \mathrm{m}$, by deep reactive ion etching (DRIE), and we tapered the microwires by a Si slow etchant (RSE-100). We and others have shown before that sputtering of materials on high-aspect-ratio microwires creates an inhomogeneous layer. ${ }^{7,45}$ The latter is solved by tapering the $\mathrm{Si}$ microwires; thereby, the microwire top does not form a shadow effect on the lower parts. Also, we taper the microwires to improve the light absorption properties by reducing the reflectivity. The height and pitch of microwires are known to have an effect on the light absorption capabilities. ${ }^{44,48,49}$ Therefore, different bare Si microwire arrays with a pitch in the range of 4-24 $\mu \mathrm{m}$ have been fabricated, and with a height varying between 0 (planar, i.e., no microwires) up to $15 \mu \mathrm{m}$. We introduced a homogeneous $\mathrm{p}-\mathrm{n}$ junction into the $\mathrm{Si}$, both in flat and in the microwire samples (Figure 1B,D). A layer of phosphorus oxide was created by depositing a spin-on dopant (SOD). After a short low-temperature drying step, a thermal drive-in diffusion process was carried out to introduce the $\mathrm{P}$ dopant into the silicon at $900{ }^{\circ} \mathrm{C}$ for $15 \mathrm{~min}$ under nitrogen flow. The junction depth was determined by the concentration of dopant and was measured to be around $900 \mathrm{~nm}$.

Electrodeposition of $\mathrm{Cu}_{2} \mathrm{O}$ on $\mathrm{Si}$ requires the presence of $\mathrm{Au}$ for uniform nucleation. On the reference stack, a $200 \mathrm{~nm}$ layer of $\mathrm{Au}$ was sputtered (Figure 1A). Au was used to form an ohmic contact to the $\mathrm{Cu}_{2} \mathrm{O}$ and to direct the growth of $\mathrm{Cu}_{2} \mathrm{O}$ in the $\langle 111\rangle$ direction, which is known to have the highest electron conductivity as compared to the other direction. ${ }^{50}$ This was followed by electrodeposition of $\sim 200 \mathrm{~nm}$ of $\mathrm{Cu}_{2} \mathrm{O}$, whereby the thickness was controlled by the deposition time. A $20 \mathrm{~nm}$ heterogeneous emitter of gallium oxide $\left(\mathrm{Ga}_{2} \mathrm{O}_{3}\right)$ and a $100 \mathrm{~nm}$ passivation/protection layer of titanium oxide $\left(\mathrm{TiO}_{2}\right)$ were both deposited by atomic layer deposition (ALD), and finally, a ruthenium oxide $\left(\mathrm{RuO}_{x}\right)$ hydrogen evolution catalyst was deposited by galvanostatic photodeposition. ${ }^{39}$

To use the underlying $\mathrm{Si}$ substrate as a photoabsorber (Figure 1B,D), the $\mathrm{Au}$ layer needs to be transparent. Therefore, the $\mathrm{Au}$ layer in Figure $1 \mathrm{~A}$ was replaced by sputtering $75 \mathrm{~nm}$ of indium-doped tin oxide (ITO) directly followed by sputtering $\sim 5 \mathrm{~nm}$ of Au nanoparticles onto planar Si (Figure 1B) or microwired Si (Figure 1C,D). Because the $\mathrm{Au}$ is being sputtered, it does not form a continuous layer, but nanoparticulate islands are formed instead. ${ }^{47}$ The transparent $\mathrm{Au}$-nanoparticle-containing layer is referred to as ITO/Au throughout the rest of the paper. Hereafter, we introduce the 

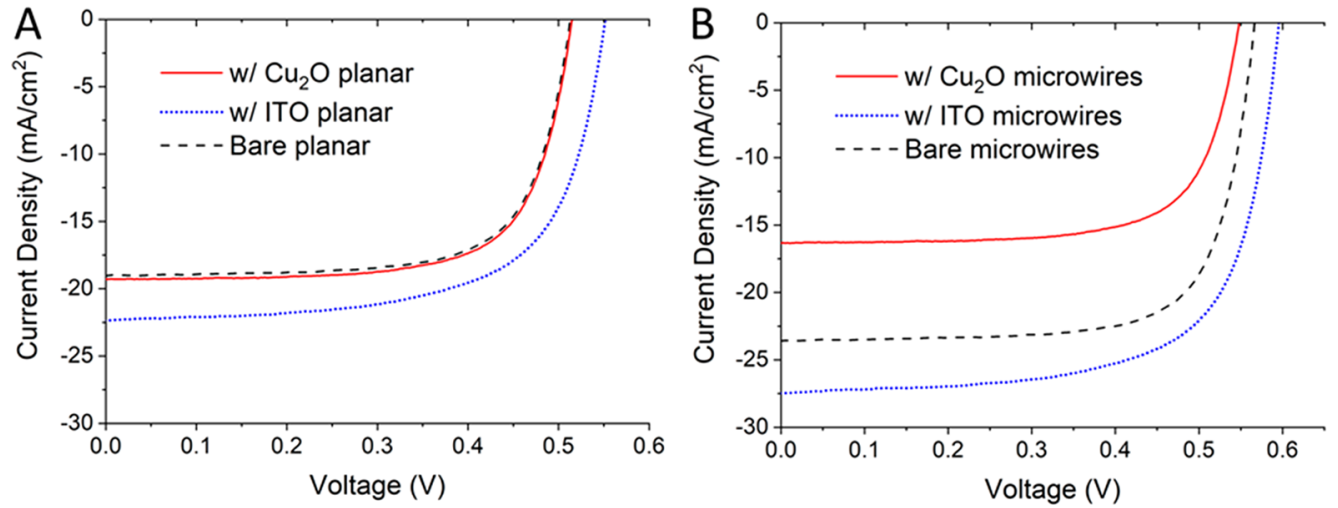

Figure 3. $J-V$ characteristics for dry Si PV cells: (A) planar and (B) microwires, with or without the different overlayers: bare (dashed), with ITO/Au (blue, dotted), and with an additional $\mathrm{Cu}_{2} \mathrm{O}$ layer on top of the ITO/Au layer (red, solid).

same $\mathrm{Cu}_{2} \mathrm{O} / \mathrm{Ga}_{2} \mathrm{O}_{3} / \mathrm{TiO}_{2} / \mathrm{RuO}_{x}$ layer stack as described above for the reference sample.

We used a mixed ITO/Au layer as a tunnel junction to stimulate conformal growth of the $\mathrm{Cu}_{2} \mathrm{O}$ while maintaining a transparent oxide conductor underneath of the stack. The idea was adapted from Dias et al., who used a transparent layer of FTO/Au as the substrate for the oxide growth. ${ }^{47}$ Here we show that the same is possible on ITO/Au. The growth was investigated by X-ray diffraction (XRD); see Figure S1. The addition of the Au particles acts clearly as a growth director in the $\langle 111\rangle$ direction, promoting columnar growth of the $\mathrm{Cu}_{2} \mathrm{O}$ layer. ${ }^{47}$ The columnar morphology is also visualized by HRSEM (see Figure S2), and the growth of the $\mathrm{Cu}_{2} \mathrm{O}$ was found to be linear with time $(\sim 6 \mathrm{~nm} / \mathrm{min})$.

The layer thickness of the $\mathrm{Cu}_{2} \mathrm{O}$ layer on the microwire samples was controlled by applying the same current density as that for a planar sample but increasing the deposition time according to the increased absolute geometric surface area due to the addition of the Si microwires. Table S1 shows the time factor for microwires with a length of $10 \mu \mathrm{m}$ and for different pitches. The thickness of the deposited $\mathrm{Cu}_{2} \mathrm{O}$ layer was investigated by HR-SEM by a cross section, as shown in Figure S3. Here two time equivalents are shown of Figure S2A,B, and the observed thicknesses correspond reasonably well to the thicknesses, as expected for a planar surface.

Figure 2 shows SEM images after each of the main process steps to fabricate the device in Figure 1D. After DRIE, the sample was immersed in a slow Si etching solution (RSE-100) for a short period of time to taper the microwires (Figure 2A). Upon sputtering of ITO, the brightness of the SEM image increased due to improved conductivity (Figure 2B). Due to the tapering of the microwires, the ITO layer is more conformal over the microwires as compared to that without tapering. ${ }^{7,45}$ Additionally, Au was sputtered over the sample, which forms most likely islands on top of the ITO layer not visible in the HR-SEM images. ${ }^{18,47}$ Because the ITO/Au layer is conducting and the electrodeposition process is masstransport-limited, a conformal layer of $\mathrm{Cu}_{2} \mathrm{O}$ was deposited over the microwires (Figures 2C and S3). Furthermore, the conformality of the complete stack of materials was investigated by cutting a finished microwire along the $z$ direction by focused ion beam (FIB) etching; see Figure 2D. The left-hand side is false-colored (as by the legend in Figure 2) to aid identification of each of the layers. The ITO layer is present completely over the Si microwire; however, within the crests of the $\mathrm{Si}$ microwire (caused by the Bosch etching process), less ITO is present due to the fact that it has been sputtered. Despite the inhomogeneity of the ITO layer, all of the consecutive layers are conformal and not hindered by the scalloping of the $\mathrm{Si}$ microwires. Especially the thin $\mathrm{Ga}_{2} \mathrm{O}_{3}$ layer is conformal over the complete structure. $\mathrm{The}^{\mathrm{TiO}} \mathrm{O}_{2}$ layer fills the remaining crests and smoothes the outside of the whole microwire.

The influence of the addition of $\mathrm{Si}$ microwires on the light absorption capabilities of solely the $\mathrm{Cu}_{2} \mathrm{O}$ and ITO/Au layers can be indirectly assessed by investigating the loss in light absorption of the underlying $\mathrm{Si}$ PV cell. We tested the underlying Si PV cell after the addition of the ITO/Au layer because it is known that ITO also acts as a passivation and antireflective layer for $\mathrm{Si}^{45}$ Therefore, to evaluate the absorption of light in the $\mathrm{Cu}_{2} \mathrm{O}$ layer, we quantified the changes in light absorption due to the addition of the ITO/Au layer and after the subsequent addition of the $\mathrm{Cu}_{2} \mathrm{O}$ layer, with and without $\mathrm{Si}$ microwires (geometry as shown in Figure $1 \mathrm{~B}, 1 \mathrm{D}$ but with $\mathrm{Cu}_{2} \mathrm{O}$ as the outer layer), as depicted in Figure 3. The different measurement setups are illustrated including contacting points to the potentiostat in Figure S4 for both a planar and microwire setup and both with and without the different overlayers.

Figure 3A shows that for a planar Si PV cell with ITO on top both the $J_{\mathrm{sc}}$ and $V_{\mathrm{oc}}$ increase due to the addition of the ITO/ Au layer. This increase is most likely due to the passivation and antireflection properties of the layer. After the addition of a $\mathrm{Cu}_{2} \mathrm{O}$ layer on a planar PV cell (with the ITO/Au layer), the $V_{\mathrm{oc}}$ and $J_{\mathrm{sc}}$ of the Si PV cell decreased again. The $J_{\mathrm{sc}}$ decreased by $4.5 \mathrm{~mA} / \mathrm{cm}^{2}$ due to the $\mathrm{Cu}_{2} \mathrm{O}$ layer when compared with only an ITO layer. The decrease in $V_{\text {oc }}$ of the planar Si PV cell is most likely due to the decrease in light intensity on the cell.

The $J-V$ characteristics of bare $\mathrm{Si}$ microwires with a radial $\mathrm{p}-\mathrm{n}$ junction were also measured (see Figure $3 \mathrm{~B}$ ). Both the $V_{\text {oc }}$ and $J_{\text {sc }}$ showed an increase with respect to a bare planar sample, which is due to the increase in light absorption capabilities of the $\mathrm{Si}$ microwires. ${ }^{51}$ When applying an ITO layer over the Si microwires, the $J_{\mathrm{sc}}$ and $V_{\mathrm{oc}}$ increased even further due to the antireflection and passivation properties. Upon addition of a $\mathrm{Cu}_{2} \mathrm{O}$ layer, a substantial decrease in $J_{s c}$ was observed. The $J_{s c}$ for a $\mathrm{Si}$ microwire PV cell with $\mathrm{Cu}_{2} \mathrm{O}$ decreased by $\sim 11 \mathrm{~mA} / \mathrm{cm}^{2}$, which indicates that the $\mathrm{Cu}_{2} \mathrm{O}$ layer absorbs even more sunlight when placed over the microwire sample as compared to the planar sample. Yet, the remaining current density (approximately $17 \mathrm{~mA} / \mathrm{cm}^{2}$ ) is sufficiently high for the Si substrate not to become the limiting 

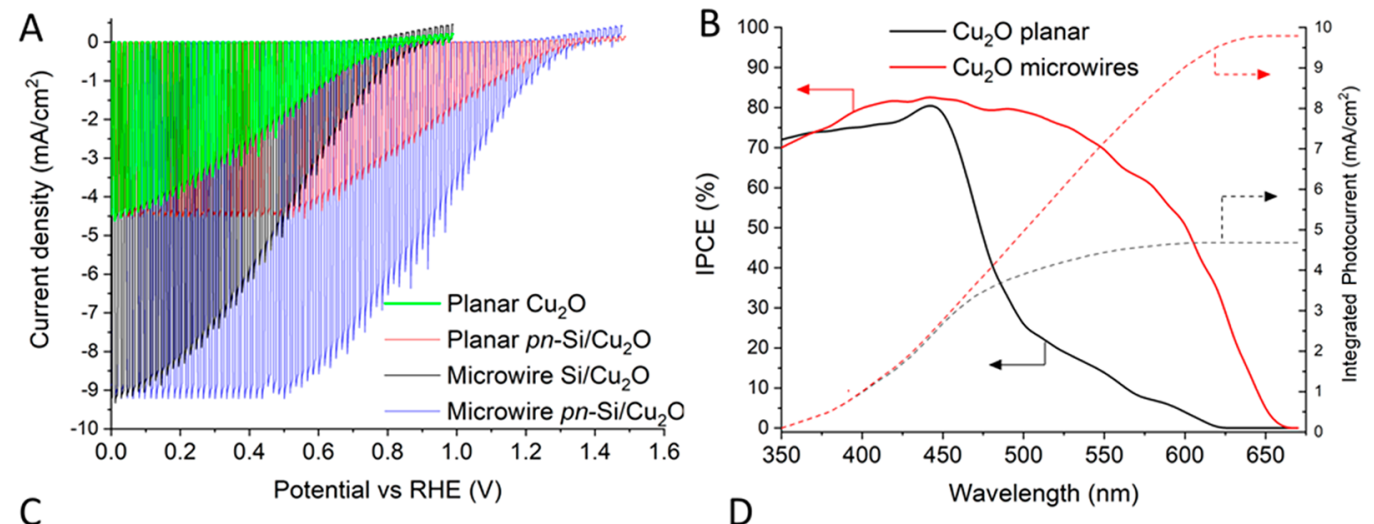

C

$\mathrm{D}$
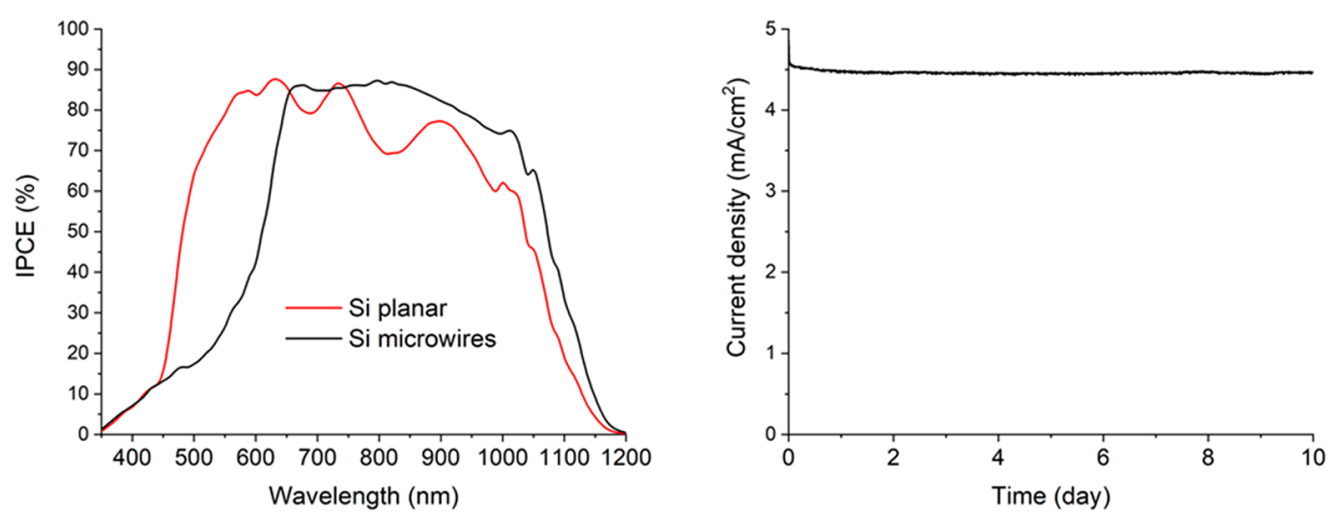

Figure 4. (A) PEC response under simulated $\mathrm{AM}$ 1.5G chopped illumination for planar $\mathrm{Si} / \mathrm{Cu}_{2} \mathrm{O}$ (green), planar $\mathrm{Cu}_{2} \mathrm{O}$ tandem with an underlying $\mathrm{Si} \mathrm{p}-\mathrm{n}$ junction (red), $\mathrm{Cu}_{2} \mathrm{O}$ on a microwire substrate (black), and $\mathrm{Cu}_{2} \mathrm{O}$ tandem on microwires with underlying $\mathrm{p}-\mathrm{n}$ junction (blue) photocathodes (geometries as shown in Figure 1A-D, respectively; the setup is shown in Figure S6). (B) Corresponding wavelengthdependent IPCE measurements for $\mathrm{Si} / \mathrm{Cu}_{2} \mathrm{O}$ planar and a microwire $\mathrm{Cu}_{2} \mathrm{O}$ top absorber with a buried radial $\mathrm{p}-\mathrm{n}$ junction (as in Figure $1 \mathrm{~B}, \mathrm{D})$. (C) Corresponding wavelength-dependent IPCE measurements for $\mathrm{Si} / \mathrm{Cu}_{2} \mathrm{O}$ planar and a microwire $\mathrm{Si}$ bottom absorber with a buried radial $\mathrm{p}-\mathrm{n}$ junction (as in Figure 1B,D). (D) PEC stability test of a $\mathrm{Cu}_{2} \mathrm{O}$ tandem cell on microwires (Figure 1D) at a fixed bias of $1 \mathrm{~V}$ versus RHE under illumination, with continuous stirring and a platinum mesh used as a counter electrode. All measurements were performed at $\mathrm{pH} 5.0$ using a combination of $0.5 \mathrm{M} \mathrm{Na}_{2} \mathrm{SO}_{4}$ and $0.1 \mathrm{M}$ phosphate solution using a three-electrode configuration.

layer in the overall current density of the device because the maximum theoretical photocurrent of the $\mathrm{Cu}_{2} \mathrm{O}$ is limited to $14.5 \mathrm{~mA} / \mathrm{cm}^{2}$. $^{32}$

Second, we fabricated microwire samples with varying pitches, microwire heights, and $\mathrm{Cu}_{2} \mathrm{O}$ thicknesses (geometry as shown in Figure $1 \mathrm{D}$ but with $\mathrm{Cu}_{2} \mathrm{O}$ as the outer layer). We screened these parameters to find the optimum current density output (Figure S5). The $\mathrm{Cu}_{2} \mathrm{O}$ layer thickness was optimized with respect to its short-circuit current density $\left(J_{\mathrm{sc}}\right)$; see Figure S5A. It was found that a $\mathrm{Cu}_{2} \mathrm{O}$ layer thickness of $\sim 150-200$ $\mathrm{nm}$ was optimal to achieve the highest $J_{\mathrm{sc}}$. Most likely, a thinner layer does not absorb all of the incoming sunlight and therefore has a lower current density output. A thicker layer, however, will absorb more of the incoming light, but electrons generated deep within the $\mathrm{Cu}_{2} \mathrm{O}$ layer will not reach the surface because of recombination within the $\mathrm{Cu}_{2} \mathrm{O}$ layer due to the limited minority carrier diffusion length of maximally $\sim 200$ nm. ${ }^{32,52,53}$

The $J_{\mathrm{sc}}$ was measured for the microwire arrays with different heights (from 0 to $15 \mu \mathrm{m}$ ), and microwires with a length of 10 $\mu \mathrm{m}$ gave the highest output (see Figure S5B). Lastly, the microwires' pitch (core to core distance) was varied from 4 to $24 \mu \mathrm{m}$. Here it was found that a smaller pitch led to a higher $J_{\text {sc; }}$ see Figure S5C. The highest tested pitch $(24 \mu \mathrm{m})$ approached the performance of a planar surface, and the microwires did not provide any gain to the light absorption anymore. The pitch of the microwire arrays cannot be smaller than $4 \mu \mathrm{m}$ because the wire width $(>2 \mu \mathrm{m})$ and combined layer thickness (of ITO, $\mathrm{Cu}_{2} \mathrm{O}$, and $\mathrm{TiO}_{2}$ ) would become higher than the pitch. Therefore, $\mathrm{Si}$ microwire arrays with a pitch of $4 \mu \mathrm{m}$, a height of $10 \mu \mathrm{m}$, and a $\mathrm{Cu}_{2} \mathrm{O}$ layer thickness of $\sim 200 \mathrm{~nm}$ were considered optimal.

Figure 4A shows the PEC performance of the four fabricated $\mathrm{Si} / \mathrm{Cu}_{2} \mathrm{O}$ photocathode samples (Figure $1 \mathrm{~A}-\mathrm{D}$ ) measured in a three-electrode configuration using the $\mathrm{Si} / \mathrm{Cu}_{2} \mathrm{O}$ photocathodes as the working electrode, a platinum mesh as the counter electrode, and $\mathrm{Ag} / \mathrm{AgCl}$ as the reference electrode (see Figure S6) under chopped light conditions. As a reference, we also provide the data obtained under continuous illumination and in the dark (Figure S7). All of the photocathodes were compared regarding the relevant values (i.e., $J_{\mathrm{ph}}$ or $J_{\mathrm{sc}} V_{\mathrm{oc}}$, fill factor (FF), and efficiency $(\eta)$ ), which are tabulated in Table 1. The efficiency was calculated as an ideal regenerative cell

Table 1. Overview of the Characteristics of the Different $\mathrm{Cu}_{2} \mathrm{O}$ Photocathodes

$\begin{array}{lcccc} & V_{\text {oc }}(\mathrm{V}) & J_{\text {sc }}\left(\mathrm{mA} / \mathrm{cm}^{2}\right) & \mathrm{FF}(\%) & \eta_{\text {irc }}(\%) \\ \text { planar } \mathrm{Si} / \mathrm{Cu}_{2} \mathrm{O} & 0.88 & -4.51 & 32.08 & 1.25 \\ \text { planar pn- } \mathrm{Si} / \mathrm{Cu}_{2} \mathrm{O} & 1.36 & -4.43 & 44.31 & 2.70 \\ \text { microwire } \mathrm{Si} / \mathrm{Cu}_{2} \mathrm{O} & 0.92 & -9.23 & 28.81 & 2.52 \\ \text { microwire pn- } \mathrm{Si} / \mathrm{Cu}_{2} \mathrm{O} & 1.34 & -9.52 & 45.07 & 5.51\end{array}$


(IRC) efficiency, which is described by an equation similar to that used to describe the efficiency of a PV device, see eq 1

$$
\eta_{\mathrm{IRC}}=\frac{V_{\mathrm{oo}} J_{\mathrm{ph}}\left(E_{\mathrm{H}_{2} / \mathrm{H}^{+}}\right) \mathrm{FF}}{P_{\mathrm{in}}}
$$

The values of FF, $V_{\mathrm{oc}}$ and $J_{\mathrm{ph}}$ in eq 1 were referenced to the equilibrium potential of the half-reaction being performed at the photocathode (the hydrogen evolution reaction), and $P_{\text {in }}$ is the light power input (AM $\left.1.5 \mathrm{G}, 100 \mathrm{~mW} / \mathrm{cm}^{2}\right)$. This equation has been chosen following Coridan et al., who proposed a unified method of comparing photoelectrodes for PEC. ${ }^{54}$ Preconditions for the application of this formula is the (reasonable) assumption that the electrochemical potential under actual hydrogen evolution conditions is at 0 vs RHE and, furthermore, that the overpotential for the $\mathrm{RuO}_{x}$ as a hydrogen evolution catalyst is not too high (which has been investigated in detail for (photo)cathodes by Pastor et al.). ${ }^{55}$ Our optimized baseline sample (see Figure 1A) is depicted in green. From Figure 4A, it becomes clear that the introduction of solely microwire structures underneath of the $\mathrm{Cu}_{2} \mathrm{O}$ (i.e., Figure 1C) has no noticeable influence on the generated photovoltage. However, by introducing a planar $\mathrm{p}-\mathrm{n}$ junction (i.e., Figure 1B) underneath of the complete stack, the photovoltage is increased to $\sim 1.36 \mathrm{~V}$, which is $\sim 500 \mathrm{mV}$ higher than our baseline (Figure 1A). The latter is in agreement with the dry PV cell measurement, as observed in Figure 3A. Furthermore, by introducing both $\mathrm{Si}$ microwires and a radial $\mathrm{p}-\mathrm{n}$ junction (i.e., Figure $1 \mathrm{D}$ ), the photovoltage is again increased to $\sim 1.34 \mathrm{~V}$ (see Figure $4 \mathrm{~A}$ ). All four measurements in Figure 4A show fluctuations in the photocurrent density due to vigorous hydrogen bubble evolution. Especially the planar pn-Si/ $\mathrm{Cu}_{2} \mathrm{O}$ (red) and microwire pn-Si/ $\mathrm{Cu}_{2} \mathrm{O}$ (blue) samples show a slight decrease in current density in the plateau region. Furthermore, a decrease in current density at around $\sim 450 \mathrm{mV}$ is observed for the microwire $\mathrm{pn}-\mathrm{Si} / \mathrm{Cu}_{2} \mathrm{O}$ sample (blue). This is most likely due to clinging of bubbles to the photocathode surface, which decreases the effective surface area until the bubbles are released.

Incorporating a $\mathrm{p}-\mathrm{n}$ junction into the $\mathrm{Si}$ does not alter the light absorption capabilities of the $\mathrm{Cu}_{2} \mathrm{O}$ layer. This is clearly visible when comparing both planar samples (with geometries as shown in Figure 1A,B), without (green) and with (red) a buried junction (see Figure $4 \mathrm{~A}$ ), which shows that the $J_{\mathrm{sc}}$ values are virtually the same. From Figure 3, it is clear that the $\mathrm{Cu}_{2} \mathrm{O}$ layer is the photocurrent-limiting layer because the underlying planar Si PV cell still generates $19 \mathrm{~mA} / \mathrm{cm}^{2}$, which is far more than the $\sim 4.5 \mathrm{~mA} / \mathrm{cm}^{2}$ produced in the PEC cell. However, the short-circuit density increased from 4.5 to 9.2 $\mathrm{mA} / \mathrm{cm}^{2}$ upon going from a flat to a microwired sample (Figure 1A,C). The $J_{s c}$ is, for the devices in series, limited by the $\mathrm{Cu}_{2} \mathrm{O}$. The increase in $J_{\mathrm{sc}}$ of the microwired structure is reflected in the increased "parasitic" absorption and reduction of $J_{s c}$ with the $\mathrm{Cu}_{2} \mathrm{O}$ layer on the dry Si PV cell, as discussed above for Figure 3.

The increase in current density is also well understood by measurements of the incident photon-to-current conversion efficiency (IPCE) of both a planar $\mathrm{Cu}_{2} \mathrm{O}$ (Figure 1A) and a microwired pn-Si/ $\mathrm{Cu}_{2} \mathrm{O}$ (Figure $1 \mathrm{C}$ ) photocathode (Figure 4B). Electrodeposited $\mathrm{Cu}_{2} \mathrm{O}$ on a planar substrate absorbs light well up to $450 \mathrm{~nm}$, beyond which the absorptivity drops rapidly to zero. The integrated photocurrent from the IPCE data combined with the AM 1.5G solar spectrum corresponds well to the value of the photocurrent presented in Figure 4A and to the current loss for a planar PV cell shown in Figure 3A. The IPCE for a microwire sample shows a broad plateau response across a wide spectral range. This broad response enhances the current density output tremendously, as is visible for both the integrated photocurrent and the output shown in Figure $4 \mathrm{~A}$, and this behavior is in accordance with the current decrease shown in Figure 3B. The increase in the IPCE values (Figure 4B), as achieved by microstructuring, resulted in an overall improved $J_{\mathrm{sc}}$ value. Our results are in agreement with those of Pan et al., ${ }^{33}$ who have shown that implementing a 3D nanostructure of $\mathrm{Cu}_{2} \mathrm{O}$ yields a broad absorption from the UV to $650 \mathrm{~nm}$. The IPCE of the bottom Si absorber is also affected by the structuring (see Figure 4C). Oscillations are visible at higher wavelengths. These are most likely due to interference between the different planar layers. These oscillations are not visible with the microwired samples due to scattering of the light within the highly structured surface. We show here that the strategy of implementing the microwire 3D structure into electrodeposited $\mathrm{Cu}_{2} \mathrm{O}$ can be utilized to harvest the red part of the incoming light. The overall regenerative efficiency is a comprehensive manner to assess the overall effect of an increase of both the $V_{\mathrm{oc}}$ and $J_{\mathrm{sc}}$. The $\eta_{\text {irc }}$ of the planar tandem PEC cell (Figure 1B) doubles with respect to our baseline planar photocathode (Figure 1A), from 1.25 to $2.70 \%$, due to the increase in photovoltage. By incorporating the $\mathrm{Cu}_{2} \mathrm{O}$ microwires (Figure 1C), the $\eta_{\text {irc }}$ again doubles as compared to our baseline planar photocathode, from 1.25 to $2.52 \%$. However, combining both systems (Figure 1D) leads to both an increased overall $J_{s c}$ due to the $\mathrm{Cu}_{2} \mathrm{O}$ microwires and a maximum obtainable $V_{\text {oc }}$ due to the underlying microwire $\mathrm{Si}$ PV cell, thereby increasing the overall efficiency from 1.25 to a record $5.51 \%$.

Lastly, we have examined the $\mathrm{TiO}_{2}$ protection layer deposited by ALD for suppressing photocorrosion. The ALD-deposited conformal $\mathrm{TiO}_{2}$ layer protects the $\mathrm{Cu}_{2} \mathrm{O}$ / $\mathrm{Ga}_{2} \mathrm{O}_{3}$ buried junction from direct contact with the electrolyte and transports the photogenerated electrons to the electrolyte where hydrogen evolution takes place (Figure S8). A PEC stability test under bias at $1 \mathrm{~V}$ vs RHE showed hardly any degradation over time (Figure 4D). Only during the first day was a slight fall in current density observed, which leveled off thereafter. Operation over a period of 10 days consecutively showed an excellent stability even under load. With more than $200 \mathrm{~h}$, this is the longest stability test reported for such $\mathrm{Cu}_{2} \mathrm{O}$ photocathodes, to the best of our knowledge. The stable operation of the $\mathrm{Si} / \mathrm{Cu}_{2} \mathrm{O}$ photocathode protected by $\mathrm{TiO}_{2}$ is attributed to three main factors: (i) the ALD-deposited $\mathrm{TiO}_{2}$ film is highly stable in aqueous media; ${ }^{12,33}$ (ii) there is no change in oxidation state of the titania film; and (iii) the HER catalyst $\left(\mathrm{RuO}_{x}\right)$ remains attached in a stable manner throughout the operation.

In summary, we have demonstrated a benchmark tandem $\mathrm{Si} / \mathrm{Cu}_{2} \mathrm{O}$ microwire photocathode featuring a current density of $9.5 \mathrm{~mA} / \mathrm{cm}^{2}$ at $0 \mathrm{~V}$ versus RHE and $4.5 \mathrm{~mA} / \mathrm{cm}^{2}$ at $+1 \mathrm{~V}$ versus $\mathrm{RHE}$ and a photovoltage of $\sim 1.4 \mathrm{~V}$ utilizing a microstructured $\mathrm{Cu}_{2} \mathrm{O}$ absorber, a $\mathrm{Ga}_{2} \mathrm{O}_{3}$ emitter layer, a $\mathrm{TiO}_{2}$ protection layer, and a $\mathrm{RuO}_{x}$ HER catalyst. The IPCE curves showed a plateau between 300 and $600 \mathrm{~nm}$ for a microstructured $\mathrm{Cu}_{2} \mathrm{O}$ layer while dropping sharply in the region between 400 and $500 \mathrm{~nm}$ for a planar sample. The microstructuring doubled the overall current density. Making 
use of the transparent interlayer of ITO/Au nanoparticles, a buried $\mathrm{p}-\mathrm{n}$ junction in $\mathrm{Si}$ can be further employed. This extra junction pushed the obtainable open-circuit potential from $\sim 1$ to $\sim 1.4 \mathrm{~V}$. All-in-all, the better light absorption and the additional voltage from the underlying buried junction increased the regenerative efficiency of $1.25 \%$ for a planar $\mathrm{Cu}_{2} \mathrm{O}$ photocathode to $5.51 \%$ for a microwired pn-Si/ $\mathrm{Cu}_{2} \mathrm{O}$ one. The stability test at $1 \mathrm{~V}$ vs RHE showed great promise to use the described geometry in a S2F device because the stability did not change over the course of 10 days even under load (at $1 \mathrm{~V}$ vs RHE). In conclusion, our results provide rational design strategies for making efficient $\mathrm{Cu}_{2} \mathrm{O}$-based photocathodes and push the frontier of PEC water splitting.

\section{ASSOCIATED CONTENT}

\section{S Supporting Information}

The Supporting Information is available free of charge on the ACS Publications website at DOI: 10.1021/acsenergylett.9b01402.

XRD patterns, HR-SEM images, area enhancement calculations, SEM images, schematic illustrations of experimental setups, plots of current density vs geometric parameters, PEC response plots, band diagram illustrations, schematic overview of the fabrication process, and the experimental section (PDF)

\section{AUTHOR INFORMATION}

\section{Corresponding Authors}

*E-mail: j.huskens@utwente.nl (J.H.).

*E-mail: david.tilley@chem.uzh.ch (S.D.T.).

\section{ORCID $\odot$}

S. David Tilley: 0000-0002-7542-1147

Jurriaan Huskens: 0000-0002-4596-9179

\section{Notes}

The authors declare no competing financial interest.

\section{ACKNOWLEDGMENTS}

Henk van Wolferen is acknowledged for the FIB experiments, and Mark Smithers is thanked for the HR-SEM images. We thank Prof. Guido Mul for use of the solar simulator. J.H. acknowledges the Institute of Advanced Study, Durham University, UK, for hosting him as a Fellow and for fruitful discussions. This work is part of the research program of the Foundation for Fundamental Research on Matter (FOM, Project 13CO12-2), which is part of The Netherlands Organization for Scientific Research (NWO). P.P.K. is grateful to the Karnataka state government for providing a scholarship under the D Devraj Urs Videshi Vyasanga Vetana scheme. We thank the Swiss National Science Foundation (AP Energy Grant \# PYAPP2 160586) and the University of Zurich Research Priority Program (URPP) LightChEC for funding.

\section{REFERENCES}

(1) Zhong, D. K.; Cornuz, M.; Sivula, K.; Grätzel, M.; Gamelin, D. R. Photo-assisted electrodeposition of cobalt-phosphate $(\mathrm{Co}-\mathrm{Pi})$ catalyst on hematite photoanodes for solar water oxidation. Energy Environ. Sci. 2011, 4, 1759-1764.

(2) Zhong, D. K.; Gamelin, D. R. Photo-electrochemical water oxidation by cobalt catalyst ("Co- $\left.\mathrm{Pi}^{\prime \prime}\right) / \alpha$ - $\mathrm{Fe} 2 \mathrm{O} 3$ composite photoanodes: Oxygen evolution and resolution of a kinetic bottleneck. $J$. Am. Chem. Soc. 2010, 132, 4202-4207.
(3) Gurudayal; Kumar, M. H.; Wong, L. H.; Barber, J.; Grätzel, M.; Mathews, N.; Sabba, D. Perovskite-Hematite Tandem Cells for Efficient Overall Solar Driven Water Splitting. Nano Lett. 2015, 15, 3833-3839.

(4) Kim, T. W.; Ping, Y.; Galli, G. A.; Choi, K.-S. Simultaneous enhancements in photon absorption and charge transport of bismuth vanadate photoanodes for solar water splitting. Nat. Commun. 2015, 6, 8769.

(5) Abdi, F. F.; Firet, N.; Van de Krol, R. Efficient BiVO4 Thin Film Photoanodes Modified with Cobalt Phosphate Catalyst and Wdoping. Chem CatChem 2013, 5, 490-496.

(6) Kim, J. H.; Jo, Y.; Kim, J. H.; Jang, J. W.; Kang, H. J.; Lee, Y. H.; Kim, D. S.; Jun, Y.; Lee, J. S. Wireless Solar Water Splitting Device with Robust Cobalt-Catalyzed, Dual-Doped BiVO4 Photoanode and Perovskite Solar Cell in Tandem: A Dual Absorber Artificial Leaf. ACS Nano 2015, 9, 11820-11829.

(7) Shaner, M. R.; Fountaine, K. T.; Ardo, S.; Coridan, R. H.; Atwater, H. A.; Lewis, N. S. Photoelectrochemistry of core-shell tandem junction $\mathrm{n}-\mathrm{p}+-\mathrm{Si} / \mathrm{n}-\mathrm{WO} 3$ microwire array photoelectrodes. Energy Environ. Sci. 2014, 7, 779-790.

(8) Miecznikowski, K.; Ramirez-Caro, A.; Fiechter, S.; Kulesza, P. J. Enhancement of Water Oxidation at Tungsten Oxide Photoanodes Doped with Borotungstate-Polyanion Modified-Hematite. Meeting Abstracts 2015, MA2015-01, 1752.

(9) Li, Z.; Yao, C.; Yu, Y.; Cai, Z.; Wang, X. Highly Efficient Capillary Photoelectrochemical Water Splitting Using Cellulose Nanofiber-Templated TiO2 Photoanodes. Adv. Mater. 2014, 26, 2262-2267.

(10) Xu, Y.; Melia, M. A.; Tsui, L.-k.; Fitz-Gerald, J. M.; Zangari, G. Laser-Induced Surface Modification at Anatase TiO2 Nanotube Array Photoanodes for Photoelectrochemical Water Oxidation. J. Phys. Chem. C 2017, 121, 17121-17128.

(11) Butburee, T.; Bai, Y.; Wang, H.; Chen, H.; Wang, Z.; Liu, G.; Zou, J.; Khemthong, P.; Lu, G. Q. M.; Wang, L. 2D Porous TiO2 Single-Crystalline Nanostructure Demonstrating High Photo-Electrochemical Water Splitting Performance. Adv. Mater. 2018, 30, 1705666.

(12) Bae, D.; Seger, B.; Vesborg, P. C. K.; Hansen, O.; Chorkendorff, I. Strategies for stable water splitting via protected photoelectrodes. Chem. Soc. Rev. 2017, 46, 1933-1954.

(13) Wang, N.; Liu, M.; Tan, H.; Liang, J.; Zhang, Q.; Wei, C.; Zhao, Y.; Sargent, E. H.; Zhang, X. Compound Homojunction:Heterojunction Reduces Bulk and Interface Recombination in $\mathrm{ZnO}$ Photoanodes for Water Splitting. Small 2017, 13, 1603527.

(14) Lamberti, A.; Gazia, R.; Sacco, A.; Bianco, S.; Quaglio, M.; Chiodoni, A.; Tresso, E.; Pirri, C. F. Coral-shaped $\mathrm{ZnO}$ nanostructures for dye-sensitized solar cell photoanodes. Prog. Photovoltaics 2014, 22, 189-197.

(15) Steinmiller, E. M. P.; Choi, K.-S. Photochemical deposition of cobalt-based oxygen evolving catalyst on a semiconductor photoanode for solar oxygen production. Proc. Natl. Acad. Sci. U. S. A. 2009, 106, 20633-20636.

(16) Masudy-Panah, S.; Siavash Moakhar, R.; Chua, C. S.; Kushwaha, A.; Dalapati, G. K. Stable and Efficient $\mathrm{CuO}$ Based Photocathode through Oxygen-Rich Composition and $\mathrm{Au}-\mathrm{Pd}$ Nanostructure Incorporation for Solar-Hydrogen Production. ACS Appl. Mater. Interfaces 2017, 9, 27596-27606.

(17) Septina, W.; Prabhakar, R. R.; Wick, R.; Moehl, T.; Tilley, S. D. Stabilized Solar Hydrogen Production with $\mathrm{CuO} / \mathrm{CdS}$ Heterojunction Thin Film Photocathodes. Chem. Mater. 2017, 29, 1735-1743.

(18) Son, M.-K.; Steier, L.; Schreier, M.; Mayer, M. T.; Luo, J.; Grätzel, M. A copper nickel mixed oxide hole selective layer for Aufree transparent cuprous oxide photocathodes. Energy Environ. Sci. 2017, 10, 912-918.

(19) Oh, J.; Deutsch, T. G.; Yuan, H.-C.; Branz, H. M. Nanoporous black silicon photocathode for $\mathrm{H} 2$ production by photoelectrochemical water splitting. Energy Environ. Sci. 2011, 4, 1690-1694.

(20) Warren, E. L.; McKone, J. R.; Atwater, H. A.; Gray, H. B.; Lewis, N. S. Hydrogen-evolution characteristics of Ni-Mo-coated, 
radial junction, $\mathrm{n}+\mathrm{p}$-silicon microwire array photocathodes. Energy Environ. Sci. 2012, 5, 9653-9661.

(21) van Dorp, D. H.; Hijnen, N.; Di Vece, M.; Kelly, J. J. SiC: A Photocathode for Water Splitting and Hydrogen Storage. Angew. Chem., Int. Ed. 2009, 48, 6085-6088.

(22) Walter, M. G.; Warren, E. L.; McKone, J. R.; Boettcher, S. W.; Mi, Q.; Santori, E. A.; Lewis, N. S. Solar water splitting cells. Chem. Rev. 2010, 110, 6446-6473.

(23) Fountaine, K. T.; Lewerenz, H. J.; Atwater, H. A. Efficiency limits for photoelectrochemical water-splitting. Nat. Commun. 2016, 7, 13706.

(24) Doscher, H.; Geisz, J. F.; Deutsch, T. G.; Turner, J. A. Sunlight absorption in water - efficiency and design implications for photoelectrochemical devices. Energy Environ. Sci. 2014, 7, 29512956.

(25) Bolton, J. R.; Strickler, S. J.; Connolly, J. S. Limiting and Realizable Efficiencies of Solar Photolysis of Water. Nature 1985, 316, $495-500$.

(26) Zhao, J.; Wang, A.; Altermatt, P. P.; Wenham, S. R.; Green, M. A. $24 \%$ efficient perl silicon solar cell: Recent improvements in high efficiency silicon cell research. Sol. Energy Mater. Sol. Cells 1996, 4142, 87-99.

(27) Shah, A.; Torres, P.; Tscharner, R.; Wyrsch, N.; Keppner, H. Photovoltaic technology: The case for thin-film solar cells. Science 1999, 285, 692-698.

(28) Saga, T. Advances in crystalline silicon solar cell technology for industrial mass production. NPG Asia Mater. 2010, 2, 96-102.

(29) Minami, T.; Nishi, Y.; Miyata, T.; Abe, S. Photovoltaic Properties in $\mathrm{Al}$-doped $\mathrm{ZnO} /$ non-doped $\mathrm{Zn1-XMgXO/Cu2O} \mathrm{Heter-}$ ojunction Solar Cells. ECS Trans. 2013, 50, 59-68.

(30) Lee, Y. S.; Heo, J.; Siah, S. C.; Mailoa, J. P.; Brandt, R. E.; Kim, S. B.; Gordon, R. G.; Buonassisi, T. Ultrathin amorphous zinc-tinoxide buffer layer for enhancing heterojunction interface quality in metal-oxide solar cells. Energy Environ. Sci. 2013, 6, 2112-2118.

(31) Minami, T.; Nishi, Y.; Miyata, T. Effect of the thin Ga2O3 layer in $\mathrm{n}+-\mathrm{ZnO} / \mathrm{n}-\mathrm{Ga} 2 \mathrm{O} 3 / \mathrm{p}-\mathrm{Cu} 2 \mathrm{O}$ heterojunction solar cells. Thin Solid Films 2013, 549, 65-69.

(32) Luo, J.; Steier, L.; Son, M.-K.; Schreier, M.; Mayer, M. T.; Grätzel, M. Cu2O Nanowire Photocathodes for Efficient and Durable Solar Water Splitting. Nano Lett. 2016, 16, 1848-1857.

(33) Pan, L.; Kim, J. H.; Mayer, M. T.; Son, M.-K.; Ummadisingu, A.; Lee, J. S.; Hagfeldt, A.; Luo, J.; Grätzel, M. Boosting the performance of $\mathrm{Cu} 2 \mathrm{O}$ photocathodes for unassisted solar water splitting devices. Nat. Catal. 2018, 1, 412-420.

(34) Lee, Y. S.; Chua, D.; Brandt, R. E.; Siah, S. C.; Li, J. V.; Mailoa, J. P.; Lee, S. W.; Gordon, R. G.; Buonassisi, T. Atomic Layer Deposited Gallium Oxide Buffer Layer Enables 1.2 V Open-Circuit Voltage in Cuprous Oxide Solar Cells. Adv. Mater. 2014, 26, 47044710.

(35) Wong, T. K. S.; Zhuk, S.; Masudy-Panah, S.; Dalapati, G. K. Current Status and Future Prospects of Copper Oxide Heterojunction Solar Cells. Materials 2016, 9, 271.

(36) Li, C.; Hisatomi, T.; Watanabe, O.; Nakabayashi, M.; Shibata, N.; Domen, K.; Delaunay, J.-J. Positive onset potential and stability of $\mathrm{Cu} 2 \mathrm{O}$-based photocathodes in water splitting by atomic layer deposition of a Ga2O3 buffer layer. Energy Environ. Sci. 2015, 8, 1493-1500.

(37) McCrory, C. C.; Jung, S.; Ferrer, I. M.; Chatman, S. M.; Peters, J. C.; Jaramillo, T. F. Benchmarking Hydrogen Evolving Reaction and Oxygen Evolving Reaction Electrocatalysts for Solar Water Splitting Devices. J. Am. Chem. Soc. 2015, 137, 4347-4357.

(38) Paracchino, A.; Laporte, V.; Sivula, K.; Grätzel, M.; Thimsen, E. Highly active oxide photocathode for photoelectrochemical water reduction. Nat. Mater. 2011, 10, 456.

(39) Tilley, S. D.; Schreier, M.; Azevedo, J.; Stefik, M.; Graetzel, M. Ruthenium Oxide Hydrogen Evolution Catalysis on Composite Cuprous Oxide Water-Splitting Photocathodes. Adv. Funct. Mater. 2014, 24, 303-311.
(40) Niu, W.; Moehl, T.; Cui, W.; Wick-Joliat, R.; Zhu, L.; Tilley, S. D. Extended Light Harvesting with Dual $\mathrm{Cu}_{2} \mathrm{O}$-Based Photocathodes for High Efficiency Water Splitting. Adv. Energy Mater. 2018, 8, 1702323.

(41) Kim, J. H.; Jang, J.-W.; Jo, Y. H.; Abdi, F. F.; Lee, Y. H.; Van de Krol, R.; Lee, J. S. Hetero-type dual photoanodes for unbiased solar water splitting with extended light harvesting. Nat. Commun. 2016, 7, 13380.

(42) Bornoz, P.; Abdi, F. F.; Tilley, S. D.; Dam, B.; Van de Krol, R.; Graetzel, M.; Sivula, K. A Bismuth Vanadate-Cuprous Oxide Tandem Cell for Overall Solar Water Splitting. J. Phys. Chem. C 2014, 118, 16959-16966.

(43) Lee, K.; Hwang, I.; Kim, N.; Choi, D.; Um, H.-D.; Kim, S.; Seo, K. 17.6\%-Efficient radial junction solar cells using silicon nano/micro hybrid structures. Nanoscale 2016, 8, 14473-14479.

(44) Elbersen, R.; Vijselaar, W.; Tiggelaar, R. M.; Gardeniers, H.; Huskens, J. Effects of Pillar Height and Junction Depth on the Performance of Radially Doped Silicon Pillar Arrays for Solar Energy Applications. Adv. Energy Mater. 2016, 6, 1501728.

(45) Vijselaar, W.; Elbersen, R.; Tiggelaar, R. M.; Gardeniers, H.; Huskens, J. Photo-Electrical Characterization of Silicon Micropillar Arrays with Radial p/n Junctions Containing Passivation and AntiReflection Coatings. Adv. Energy Mater. 2017, 7, 1601497.

(46) Dahl, S.; Chorkendorff, I. Solar-fuel generation: Towards practical implementation. Nat. Mater. 2012, 11, 100-101.

(47) Dias, P.; Schreier, M.; Tilley, S. D.; Luo, J.; Azevedo, J.; Andrade, L.; Bi, D.; Hagfeldt, A.; Mendes, A.; Grätzel, M.; Mayer, M. T. Transparent Cuprous Oxide Photocathode Enabling a Stacked Tandem Cell for Unbiased Water Splitting. Adv. Energy Mater. 2015, 5,1501537

(48) Vijselaar, W.; Westerik, P.; Veerbeek, J.; Tiggelaar, R. M.; Berenschot, E.; Tas, N. R.; Gardeniers, H.; Huskens, J. Spatial Decoupling of Light absorption and Catalytic Activity of NiMoloaded High-aspect-ratio Silicon Microwire Photocathodes. Nature Energy 2018, 3, 185-192.

(49) Elbersen, R.; Vijselaar, W.; Tiggelaar, R. M.; Gardeniers, H.; Huskens, J. Fabrication and Doping Methods for Silicon Nano- and Micropillar Arrays for Solar-Cell Applications: A Review. Adv. Mater. 2015, 27, 6781-6796.

(50) Huang, M. H. Facet-Dependent Optical Properties of Semiconductor Nanocrystals. Small 2019, 15, 1804726.

(51) Elbersen, R.; Tiggelaar, R. M.; Milbrat, A.; Mul, G.; Gardeniers, H.; Huskens, J. Controlled Doping Methods for Radial p/n Junctions in Silicon. Adv. Energy Mater. 2015, 5, 1401745.

(52) Zhang, Z.; Dua, R.; Zhang, L.; Zhu, H.; Zhang, H.; Wang, P. Carbon-Layer-Protected Cuprous Oxide Nanowire Arrays for Efficient Water Reduction. ACS Nano 2013, 7, 1709-1717.

(53) de Jongh, P. E.; Vanmaekelbergh, D.; Kelly, J. J. Cu2O: Electrodeposition and Characterization. Chem. Mater. 1999, 11, $3512-3517$

(54) Coridan, R. H.; Nielander, A. C.; Francis, S. A.; McDowell, M. T.; Dix, V.; Chatman, S. M.; Lewis, N. S. Methods for Comparing the Performance of Energy-conversion Systems for Use in Solar Fuels and Solar Electricity Generation. Energy Environ. Sci. 2015, 8, 2886-2901.

(55) Pastor, E.; Le Formal, F.; Mayer, M. T.; Tilley, S. D.; Francàs, L.; Mesa, C. A.; Grätzel, M.; Durrant, J. R. Spectroelectrochemical analysis of the mechanism of (photo)electrochemical hydrogen evolution at a catalytic interface. Nat. Commun. 2017, 8, 14280. 